\title{
CORRECTION
}

\section{Correction: Telomere length and genetics are independent colorectal tumour risk factors in an evaluation of biomarkers in normal bowel}

Ceres Fernandez-Rozadilla ${ }^{1}$, Christiana Kartsonaki ${ }^{2}$, Connor Woolley ${ }^{1}$, Michael McClellan ${ }^{3}$, Deb Whittington ${ }^{4}$, Gareth Horgan ${ }^{4}$, Simon Leedham ${ }^{4,5}$, Skirmantas Kriaucionis ${ }^{3}$, James E. East ${ }^{4,6}$ and lan Tomlinson ${ }^{1,7}$

British Journal of Cancer (2018) 118:1683; https://doi.org/10.1038/s41416-018-0111-0

Correction to: Br J Cancer (2018) 118: 727-732; https://doi.org/ 10.1038/bjc.2017.486; published online 13 February 2018

Since the publication of this paper, the authors noticed that James E. East was assigned to the incorrect affiliation. The affiliation information is provided correctly, above.

Furthermore, the authors would like to add the following information to the Acknowledgements section:

\section{ACKNOWLEDGEMENTS}

James E. East was funded by the National Institute for Health Research (NIHR) Oxford Biomedical Research Centre (BRC). The views expressed are those of the author(s) and not necessarily those of the NHS, the NIHR or the Department of Health. (i) Open Access This article is licensed under a Creative Commons Attribution 4.0 International License, which permits use, sharing, adaptation, distribution and reproduction in any medium or format, as long as you give appropriate credit to the original author(s) and the source, provide a link to the Creative Commons license, and indicate if changes were made. The images or other third party material in this article are included in the article's Creative Commons license, unless indicated otherwise in a credit line to the material. If material is not included in the article's Creative Commons license and your intended use is not permitted by statutory regulation or exceeds the permitted use, you will need to obtain permission directly from the copyright holder. To view a copy of this license, visit http://creativecommons. org/licenses/by/4.0/.

(c) The Author(s) 2018

\footnotetext{
'Molecular and Population Genetics Laboratory University of Oxford, Oxford OX3 7BN, UK; ${ }^{2}$ Clinical Trial Service Unit and Epidemiological Studies Unit, Nuffield Department of Population Health, Old Road Campus, Oxford OX3 7DQ, UK; ${ }^{3}$ Ludwig Institute for Cancer Research, University of Oxford, Old Road Campus Research Building, Roosevelt Drive, Oxford OX3 7DQ, UK; ${ }^{4}$ Translational Gastroenterology Unit, Experimental Medicine Division, Nuffield Department of Clinical Medicine, John Radcliffe Hospital, Oxford OX3 9DU, UK; ${ }^{5}$ Gastrointestinal Stem Cell Biology Laboratory, Oxford Centre for Cancer Gene Research, Oxford, UK; ${ }^{6}$ Oxford NIHR Biomedical Research Centre, University of Oxford, Oxford, UK and ${ }^{7}$ Institute of Cancer and Genomic Sciences, College of Medical and Dental Sciences, University of Birmingham, Vincent Drive, Edgbaston, Birmingham B15 $2 \pi T$, UK Correspondence: Ian Tomlinson (iant@well.ox.ac.uk)
}

Published online: 21 May 2018 